\title{
CRIMINAL ATTEMPT IN THE MALAYSIAN COMPUTER CRIMES ACT 1997 (ACT 563)
}

\author{
Ammar Abdullah Saeed Mohammed ${ }^{1}$ \\ PhD Student, Faculty of Law and International Relations, \\ Universiti Sultan Zainal Abidin (UniSZA), Malaysia \\ (Email: ammarabdullah817@gmail.com) \\ Nazli Ismail Nawang ${ }^{2}$ \\ Senior Lecturer, Faculty of Law and International Relations, \\ Universiti Sultan Zainal Abidin (UniSZA), Malaysia \\ (Email: inazli@unisza.edu.my) \\ Aminuddin Mustaffa ${ }^{3}$ \\ Senior Lecturer, Faculty of Law and International Relations \\ Universiti Sultan Zainal Abidin (UniSZA), Malaysia \\ (Email: aminuddinm@unisza.edu.my)
}

Accepted date: $22-02-2019$

Published date: 10-07-2019

To cite this document: Mohammed, A. A. S., Ismail Nawang, N., \& Mustaffa, A. (2019). Criminal Attempt in the Malaysian Computer Crimes Act 1997 (Act 563). International Journal of Law, Government and Communication, 4(15), 01-07.

DOI: $10.35631 /$ ijlgc.415001

\begin{abstract}
A criminal attempt is an offence in traditional laws as it may cause either damage or the danger of damage. Nonetheless, uncertainty arises with regards to cybercrimes arguably due to the lack of critical attention paid to attempt of committing cybercrime by other researchers in this area. As such, this paper intends to analyse the position of the criminal attempt which is explicitly stipulated in section 7 of the Computer Crimes Act 1997 (CCA). Further, this paper aims to demonstrate related legal issues pertaining to criminal attempt in cybercrimes including mere preparation and its relation to criminal attempts of cybercrimes, mens rea in committing criminal attempt, recklessness in criminal attempt of cybercrimes as well as impossibility defences for cybercrime attempts. In so doing, section 7 of the CCA will be critically scrutinised in solving those issues. Apart from that, the paper will also examine relevant decided cases on criminal attempts for traditional criminal offences. To sum up, merely preparation in cybercrime shall be an attempt, and mens rea is required in a criminal attempt to commit cybercrime but in certain situations knowledge of the risk is enough to be an attempt to commit cybercrime offences.
\end{abstract}

Keywords: Cybercrime, Criminal Attempt, Merely Preparation, Impossibility Defences, Mens Rea

\section{Introduction}

In criminal law, an attempt is an offence as it causes either damage or the danger of damage. For instance, if a man with the intent to kill another man, shoots him but fails to kill him, this 
is an attempt to murder because of the damage to the victim. Likewise, if with the same intent he shoots at, but misses, the other man, who is unaware of the shooting, is likewise a victim of an attempt to murder because of the danger of damage (Edwin R. Keedy, 1954). A criminal attempt has been criticised as it is still somewhat enigmatic and complicated. This is due to several factors including the lack of an accurate legal definition; the mental and physical ingredients vary considerably with the nature of the attempted offence; and the possibility of the offence's interpretation by the courts that can be 'broad' or 'narrow' (KN Chandrasekharan Pillai \& Shabistan Aquil, 2005). Nevertheless, since there might potentially be damage or the danger of damage to the intended victims, therefore such an attempt cannot simply be left without criminalization (Murat C. Mungan, 2019). In relation thereof, this paper intends to scrutinise the offence of criminal attempt to commit cybercrime under the CCA.

\section{Criminal Attempt of Cybercrime under the CCA}

Attempting to commit or doing any act preparatory to the commission of the offences is an offence under the CCA. Section 7(1) explicitly provides that:

"A person who abets the commission of or who attempts to commit any offence under this Act shall be guilty of that offence and shall on conviction be liable to the punishment provided for the offence".

Further section 7(2) states that:

"A person who does any act preparatory to or in furtherance of the commission of any offence under this Act shall be guilty of that offence and shall on conviction be liable to the punishment provided for the offence. Provided that any term of imprisonment imposed shall not exceed one-half of the maximum term provided for the offence".

The aforesaid provisions have clearly stipulated that both attempt and preparatory to commit cybercrimes are offences under the CCA. In criminal law, it is obviously difficult to draw a line between the preparatory stage and attempt. The offence of the attempt may require a test of proximity in establishing the said offence, whilst preparation to commit an offence is not considered as an offence according to section 511 of the Penal Code, but it has been made an offence under section 7(2) of the CCA 1997 (Julian Ding, 1999).

There is no specific statutory definition of the term 'attempt' in the CCA. However, references may be made to the Indian case of State of $U v$ Ram Chaiar (1962) whereby the term 'attempt' has been interpreted as "an intentional act which a person does towards the commission of an offence, but which fails in its object through circumstances independent of the volition of that person".

Similarly, in Kailash Chandra Parekh v State of Assam (2003) the court ruled that the term 'attempt' refers to "an attempt to commit an offence, which, due to some interruptions beyond the control of the doer, remained unaccomplished". An attempt to commit an offence can be said to commence the moment when preparations are complete, and the offender then does something with the intention of committing the offence and which is a step towards the commission of the offence. According to this, an attempt is an inchoate offence with intent, furthermore, in criminal attempt preparations are complete but the criminal result could not be achieved due to the circumstances beyond of control.

In the UK, the concept of 'criminal attempt' is provided for by section 1(1) of the Criminal Attempts Act 1981 that "if a person does an act which is more than merely preparatory to the 
commission of an offence". Therefore, attempt to commit conventional crimes is an offence and it must go beyond mere preparation to commit the crime. Moreover, the mens rea is required in criminal attempt offence under traditional laws and it requires the fulfilment of two elements; firstly, the defendant must have intent to commit an offence and it starts with the conducts which are necessary for achieving the result, and secondly the defendant must have an intent to achieve the result of the offence itself i.e. he must have an actual desire to the criminal result (Dutta Aparajita, 2017).

Pertaining to the position in Malaysia, in Thiangiah \& Anor v Public Prosecutor (1977), Ajaib Singh J defined the term as "an attempt to commit a crime is an act done with intent to commit that crime, and forming part of a series of acts, which would constitute its actual commission if it were not interrupted". According to this definition, criminal attempt requires criminal intent which is the mens rea element.

In cybercrime, an attempt has also crucial importance to criminalize actions of preparing to commit a crime that may cause damage or danger of damage. A good illustration would be when a person downloaded an application for hacking another person's email and started to do hacking, but was unsuccessful in accomplishing his mission for a reason which is out of his control. In this example, even though the person does not achieve the result but his attempt was with intent and it was obvious when he downloaded the hacking software tool to start his criminal act and this preparation shall be a strong presumption of intent to commit a crime.

However, an issue arises as to whether merely preparation is considered as an attempt to commit a crime. In Thiangiah \& Anor v Public Prosecutor (1977), the court stated that "There must be some further overt act on the part of the offender which is directed towards the actual commission of the crime and which is immediately and not remotely connected with the crime in order to constitute an attempt within the meaning of section 511 of the Penal Code." Therefore, in traditional crimes, the act in criminal attempt must be more than merely preparatory to the commission of an offence, whilst in cybercrime the situation might be different. Merely preparation may be considered as an attempt because of the difficulty to draw the line between preparation and merely preparation as in cybercrime the result can be achieved by one click of the mouse in coding hacking offence for example. Moreover, contrary to section 511 of the Penal Code and section 7(2) of the CCA states that merely preparation is an attempt and shall be punished.

\section{Is Mens Rea Required in Criminal Attempt of Cybercrime?}

An attempt occurs when a person has intent for the commission of a crime and takes a substantial step to complete the crime, but the actual crime is not realised for reasons that are out of his control (John Kaplan, Robert Weisberg \& Guyora Binder, 2017). Criminal attempt requires two basic elements which are actus reus (the guilty act) and mens rea (the intent).

However, an issue arises as to whether the intent is required in an attempt to commit cybercrime like a criminal attempt for traditional crimes. For example, a person who enjoys hacking computers for fun without intent to cause damage, but could not obtain his desired result for a reason out of his control, this is an offence of hacking attempt. Despite the fact that he knows his unauthorised acts could cause damage or danger of damage to the targeted computer networks or data, therefore, in this example, as there is no criminal intent, but the offender's knowledge may amount to mens rea as he knows that his access is unauthorised, his act may cause damage or could be danger of damage. 
Although, mens rea is required in cybercrime cases, under section 6 (1) of the CCA, mens rea is not required in wrongful communication offence as it states that "A person shall be guilty of an offence if he communicates directly or indirectly a number, code, password or other means of access to any person other than a person to whom he is duly authorized to communicate". Accordingly, the offender will be punished whether the disclosure of number, code, password or other means of access to a computer was directly or indirectly.

Consequently, it could be submitted that similar to traditional crimes, mens rea is required except offences that fall under strict liability offences. However, due to the uniqueness of cybercrimes, mens rea (criminal intent) may not be required in certain cases including an attempt of committing cybercrime due to the strict liability nature of the offences because it is the most dangerous criminal threats with serious consequences.

\section{Liability of Recklessness in Criminal Attempt of Cybercrimes}

As mentioned earlier, intention is the substance of criminal attempt in traditional crimes (Gideon Yaffe, 2014). Therefore, only a direct and specific intention must be shown to support the conviction. However, it is unclear whether recklessness would be a sufficient mens rea. In State v. Lyerla (1988), the defendant randomly shot into a truck for three times and the driver of the truck was killed by one shot but no harm was inflicted to the other two passengers. The court ruled that the defendant was guilty of the reckless second-degree murder of the driver, but was not guilty of recklessly attempting to murder the passengers as the court justified that criminal attempt requires a higher level of intent rather than recklessness.

On the contrary, in $R v$ Khan (1990), the four appellants tried unsuccessfully, to have sexual intercourse with a 16 years old girl and they were charged with attempted rape. At the trial, a question was raised as to whether the girl's consent was considered as they could be guilty of an attempt either they knew that the girl did not consent to the sexual intercourse or was reckless as to whether she consented to it or not. The court held that recklessness as to the circumstance was sufficient for attempted rape.

Consequently, it is submitted that, recklessness might not suffice mens rea to criminal attempt in traditional crimes since it requires a high level of intent to commit the crime. However, it is unclear whether recklessness would constitute a sufficient mens rea in attempt to commit cybercrime under section 7 of the CCA. Recklessness means being aware of a substantial risk, and it was unjustifiable to take that risk (Nelson Chan, Simon Coronel \& Yik Chiat Ong, 2003). As mens rea is required in the criminal attempt to commit cybercrimes, therefore, an attempt to commit any offence under section 7 of the CCA whether intentionally or recklessly would be punished. However, it could be submitted that for the recklessness in criminal attempt to commit cybercrime, the person should have a minimum awareness of knowledge that his doing is illegal or cause damage. In addition, his acts are unjustifiable to take that risk as it is impossible to imagine a person who uses the computer is not aware of a substantial risk his doing.

\section{The impact of Impossibility Defences in Cybercrimes}

Attempt liability is a unique case. This is because no immediate objective harm when the act is incomplete as attempt offences only may cause damages or danger to damages. Therefore, the court may face difficulties to impose punishment for such acts (Kayla Barkase \& David MacAlister, 2014). Impossibility in the criminal attempt is a defence that can be used when the defendant failed to achieve the criminal result that might be because the crime was factually or legally impossible to commit (Daniel Yeager, 2018). In the criminal attempt, there are two 
common defences of impossibility that can be used to defend the accused of committing a crime, namely; factual impossibility and legal impossibility (Richard M. Bonnie, Anne M. Coughlin, John C. Jefferies Jr. \& Peter W. Low, 2010).

Factual impossibility may be used when the intended crime could not be accomplished because of some physical impossibility, for reasons unknown to the accused. For example; if A throws an animal food with rat poison into the neighbour's yard with intent to poison the neighbour's dog, believing that the dog is inside the house's yard, but the dog is outside and does not eat the food. Therefore, this mistake of fact will not excuse A's attempt to kill the neighbour's dog. In this case, the illegal act cannot physically be accomplished. In Lamont $v$ Strathern (1933) the accused had tried to pick his victim's pocket, but there had been nothing in it to steal. He was convicted of attempted theft offence because the accused had taken his planned acts through to be completed as he could, but he was only failed when he had found the pocket empty.

In Malaysia, the legal framework relating to criminal attempt is stated in section 511 of the Penal Code which provides that:

"Whoever attempts to commit an offence punishable by this Code or by any other written law with imprisonment or fine or with a combination of such punishments, or attempts to cause such an offence to be committed, and in such attempt does any act towards the commission of such offence, shall, where no express provision is made by this Code or by such other written law, as the case may be, for the punishment of such attempt, be punished with such punishment as is provided for the offence: Provided that any term of imprisonment imposed shall not exceed one-half of the longest term provided for the offence."

The section does not specifically deal with impossibility in attempt to do an offence but the illustrations of this section show that if a person attempts to steal some jewels from an empty jewel box or something from an empty pocket he will be held guilty. According to the illustrations, the most important criteria is the person's belief and the intent to break the box and steal the jewels. It does not matter if there are no jewels in the box, it could be understood that a person shall be liable for criminal attempt and factual impossibility in criminal attempt under Malaysian legal framework is not valid defence as the defendant the criminal intent is available, and the result not achieved because some reasons or circumstances beyond of his control prevented the result.

Factual impossibility can take place in cybercrime and it should have the same legal status with factual impossibility in traditional crimes. It would be unreasonable to exempt the actor when he attempts to commit cybercrime but could not achieve the criminal result for reasons beyond his control. For example, , if someone had unauthorized access to the victim's bank account successfully, but was no balance the victim's bank account, or the victim account informed the bank that his account had been hacked then the account was closed by the bank which made the offender not able to transfer money or to do any transaction, so, the offence is not complete because the bank account was empty or was blocked by the bank which means factual impossibility.

The second category of impossibility is legal impossibility which is a traditional criminal attempt defence in common law. Legal impossibility arises when the completed criminal act would not amount to a crime (John Kaplan, Robert Weisberg \& Guyora Binder, 2017). The 
legal impossibility may arise where the offender believes that what he or she is attempting to do is illegal, but his act does not amount to a crime (Dutta Aparajita, 2017).

Legal impossibility is divided into two subcategories: pure legal impossibility and hybrid legal impossibility. Pure legal impossibility arises when the result that has been achieved by the defendant is not proscribed. While hybrid legal impossibility if the criminal object is illegal but it is impossible because of the factual mistake related to the legal status relevant to the conduct (John Kaplan, Robert Weisberg \& Guyora Binder, 2017). For example, a person who attempted to bribe someone whom he mistakenly believes that person is responsible for his deals in a specific institution, so he is not liable for bribery attempted crime. This is a valid defence as can be seen in Haughton $v$ Smith (1975) whereby police officers stopped a large van on a highway found that it contains stolen goods, the driver and another man in the van were brought to a police station. they were allowed to continue their drive along the highway to a service area and police officers following them, the defendant was waiting for the goods at the service area for disposal of the goods then he was arrested and convicted for attempting to handle stolen goods, the defendant argued that he should not be convicted of attempting the impossible, since the goods were no longer stolen, the Court of Appeal allowed the appeal.

Contrary to factual impossibility, legal impossibility that cannot be conceived of in cybercrime, the average person cannot believe that what he or she is attempting to do is illegal, but his act is not a crime, because if the person attempts to commit an unauthorised access or unauthorised modification, therefore, he is fully aware that his act is illegal. However, legal impossibility is not a valid defence in cybercrime.

\section{Conclusion}

In conclusion, it could be submitted that, merely preparation in cybercrime shall be considered as an attempt because it is difficult to draw the line between preparation and mere preparation. In addition, the criminal result in cybercrime can be achieved at the push of a button on the keyboard. This paper has shown that mens rea under section 7 CCA 1997 is required in the criminal attempt. However, as cybercrime is the most dangerous criminal threats with serious consequences, mens rea may not require in some situations, such as a person who engages in favour of hacking computers for fun without intent to cause damage, just for fun, but his conduct could cause damage or danger of damage to the computer.

Furthermore, it could be concluded that, a person who engaged in criminal attempt under section 7 of the CCA whether intentionally or recklessly shall be punished, however, the person should have a minimum awareness of knowledge that his doing is illegal, may cause damage and acts are unjustifiable to take that risk.

Finally, factual impossibility can be conceived of in cybercrime, but it is not a valid defence, on the other hand, legal impossibility cannot be conceived of in cybercrime, therefore, impossibility is not valid defences in cybercrime.

\section{References}

Aparajita, D. (2017). An Analysis of the Law of Criminal Attempt with Special Reference to the Indian Panel Code 1860. PhD thesis, Department of law, University of Gauhat i- India. available at http://hdl.handle.net/10603/149699

Barkase, K. \& MacAlister, D. (2014). Impossibility in the Law of Criminal Attempt: A Comparison of Canada, Australia and New Zealand, Oxford University Commonwealth Law Journal, 14:2, 153-194, DOI: 10.1080/14729342.2015.1047648 
Bonnie, R. M., Coughlin, A. M., Jefferies Jr., J. C. \& Low, P. W. (2015). Criminal Law. Westbury, NY: The Foundation Press.

Chan, N., Coronel, S. and Ong, Y.C. (2003). The Threat of the Cybercrime Act 2001 to Australian IT Professionals, in Proceedings of the First Australian Undergraduate Students Computing Conference, 25 - 33.

Ding, J. (1999). E-Commerce: Law \& Practice. Malaysia; Singapore: Sweet \& Maxwell.

Kaplan, J., Weisberg, R., and Binder, G. (2017). Criminal Law: Cases and Materials. New York: Wolters Kluwer.

Keedy, E. R. (1954). Criminal Attempts at Common Law. University of Pennsylvania Law Review. Vol. 102, $464-489$.

Mungan, M. C. (2019). Abandoned Criminal Attempts: An Economic Analysis. Alabama Law Review. Vol. 67, $1-43$.

Pillai, KN. C. \& Aquil, S. (2005). Essays on the Indian Penal Code. New Delhi: Indian Law Institute.

Yaffe, G. (2014). Criminal Attempts. Yale Law Journal. Vol.124, 92 - 156.

Yeager, D. (2018). Decoding the Impossibility Defense. University of Louisville Law Review, Vol. 56, $356-379$.

U v Ram Chaiar AIR 1962 All 359.

Kailash Chandra Parekh v State of Assam (2003) Cr .LJ 3514 (Gau).

Thiangiah \& Anor v Public Prosecutor [1977] 1 MLJ 79.

State v. Lyerla, 424 N.W.2d 908 (SD: Supreme Court 1988).

$R v$ Khan [1990] 2 All ER 783, [1990] 1 WLR 813.

Lamont v. Strathern - 1933 JC 33.

Haughton v Smiththe [1975] AC 476.

Britton v Alpogut [1987] VR 929. 